\title{
Earth Resources Exploitation and Sustainable Development: Geological and Engineering Perspectives
}

\author{
C. C. Iwuji, O. C. Okeke, B. C. Ezenwoke, C. C. Amadi, H. Nwachukwu \\ Department of Geology, Federal University of Technology, Owerri, Nigeria \\ Email: geocally@yahoo.com
}

Received 23 November 2015; accepted 18 January 2016; published 21 January 2016

Copyright $@ 2016$ by authors and Scientific Research Publishing Inc.

This work is licensed under the Creative Commons Attribution International License (CC BY). http://creativecommons.org/licenses/by/4.0/

cC) (i) Open Access

\begin{abstract}
Earth resources are the essential basis for an economy of a country and well-being of her citizens. Their exploitation is a key factor in economic growth and development of the nation, but one that can have serious negative environmental and socio-economic impacts. Therefore it is important to understand their origin/occurrence and exploitation in terms of environmental sustainability. The human society has profited from exploitation of earth resources, precisely when energy use became much more efficient during the industrial era. Some of these earth resources (renewable and non-renewable) are oil and gas, coal, water, metal ore, wind, air etc. and their methods of exploitation are surface and subsurface mining methods [1]. Thus the geological perspectives of earth resources refer to origin and occurrence of these earth resources while the engineering perspectives refer to the processes involved in the extraction (mining), processing and utilization of the resources. To fulfill the requirement of sustainable development, the efficiency with which resources are utilized has to be improved. The main concerns associated with earth resources, therefore, are generally the costs and environmental impacts of extracting, transporting, and refining them. The economics of earth resources deals with the supply, demand and allocation of the resources.
\end{abstract}

\section{Keywords}

Earth Resources, Exploitation, Sustainable Development, Geological and Engineering Perspectives

\section{Introduction}

The Earth resources are referred to as natural resources and that are useful raw materials for manufacturing/

How to cite this paper: Iwuji, C.C., Okeke, O.C., Ezenwoke, B.C., Amadi, C.C. and Nwachukwu, H. (2016) Earth Resources Exploitation and Sustainable Development: Geological and Engineering Perspectives. Engineering, 8, 21-33. 
production of goods. They occur naturally, meaning that man cannot make them but instead use and modify the resources in ways that are beneficial. These resources include minerals such as fossil fuels, solid minerals, air, water, soil, wind, geothermal, tidal, and solar energy. Hence, earth resources are grouped into: 1) Renewable resources: this implies that they are replaced or regenerated naturally for example tides, solar power and wind energy, water etc. 2) Non-renewable resources: these are earth resources that cannot be replaced or regenerated naturally or otherwise for example coal, petroleum, metals etc.

The word "sustainable" means able to be maintained. Sustainability is defined as the process applied to aid the quality of human life within the limitations of the environment. The United Nations World Commission on Environment and Development coined a definition of sustainable development, which is probably the most well known in all of the sustainability literature: "development that meets the needs of the present without compromising the ability of future generations to meet their own needs" [2]. However, sustainable development implies a dynamic balance between maintenance/conservation (sustainability) and development [3], both directed towards human needs. The concept of sustainable development therefore involves the successful integration of environmental considerations into development management [4]. Sustainability is in turn defined by Lawrence as meeting the ecological, social and economical needs and aspirations of human and other species [5].

In practical, non-renewable resources are not fully exhausted or exploit all the renewable resources. Hence, the most valuable deposits and sites are discovered and exploited first, followed by other less quality sources as demand increases. As demand increases and scarcity of resources set in, its price increases. Thus reduction in demand gives explorers incentives to look out for sources that are of lower quality and/or more expensive to exploit, and to improve methods for locating, extracting, and processing the resources. Increasing prices also encourage the development of substitutes that were less demanded when then original resource was cheap.

Sustainable development requires the maintenance, rational use and enhancement of natural resources, as well as a balanced consideration of ecology, economy and social justice. More so, it involves solutions for improving human welfare that does not result in degrading the environment on impinging in well-being other people [6] [7]. Industrialized countries have to transfer their advanced technologies to developing countries in order to avoid undesirable development in the mining industry and use of natural resources in those regions. Hence, people who study energy resources seek to know the type of resources that are available and where they are located, and to create new methods for locating, extracting, and exploiting the resources. Discovery of new sources of supplies and using more energy resources is one way to derive more benefits [8]. But we can also use these resources more efficiently, so that we can obtain a rising amount of service from a constant level of inputs.

\section{Overview of Earth Resources and Sustainable Development}

\subsection{Earth Resources}

The earth is rich in natural resources that we use every day. These resources are very economical materials of geologic origin that can be extracted from the earth. However, earth resources are classified into: 1) non-renewable resources: suggest that they are natural resources that are not replaced or re-growth naturally. These resources are exhaustible and are extracted faster than the rate at which they formed [9] [10]. Some common examples are fossils fuels (coal, oil, and natural gas), precious gems and metals and ores etc.

2) Renewable resources are replaced through natural processes at a rate that is equal to or greater than the rate at which they are exploited, and depletion is usually not a threat. Some common examples include; air (wind), water, soil, trees, sun-light etc. Though many renewable resources do not have such a rapid recovery rate, these resources are susceptible to depletion by over-use. Resources from a human use perspective are classified as renewable only so long as rate of replacement exceeds that of the rate of consumption [11].

\subsection{The Notion of Sustainable Development}

Sustainable development is a normative term-according to the philosopher Immanuel Kant-like liberty and equality. In the UN report “Our Common Future”, commonly called the Brundtland Report, sustainable development is suggested to be development that meets the needs of the present without compromising the ability of the future to meet their own needs [2]. However, this definition was expanded by the United Nations Environment Programme (UNEP), which has added that this notion also requires the maintenance, rational use, and enhancement of the natural resources base that underpins ecological resilience and economic growth, and that it implies progress towards international equity [12]. 
The next level was the Rio declaration at the UN conference on Environment Development in Rio de Janeiro in 1992 and Agenda 21, which stresses the three elements of sustainable development-economy, ecology, and social justice. To conserve the basic needs of life and also to enable all people to achieve economic success, and to strive towards social justice. All three objectives should initially be considered to have the same priority. While the definition above emphases intergeneration fairness. The first real guidelines for sustainable development came from the German forestry administration.

The man credited with inventing sustainable development was a miner, Oberberghauptmann Johnann-karl Von carlowitz. He was the head of the mining administration of the famous silver-mining district in freiberg, Saxony. Meanwhile, he was not only responsible for the mining and smelting operations in this district, but also for forestry, because timber was needed in the underground mining operations, and the smelting of the silver ores required vast amounts of wood for charcoal. He realized that unchecked deforestation for these purposes would lead to the collapse of timber production. He was the first person to spell out what sustainable development meant in forestry, that the amount of wood cut should not exceed the regeneration rate.

\section{Sustainable Use of Earth Resources}

The issue of depletion plays an important role in the use of non-renewable and renewable earth resources. In the renewable resources, depletion occurs when extraction exceeds renewal rate. Flow and environmental resources are not depleted and always exist. However, environmental resources can be degraded by pollution, and contamination, rendered useless. The way development takes place at the moment is extremely wasteful of natural resources.

More so, proper resources uses are the backbone of every economy and provide two basic functions; raw material for production of goods and services, and environmental service.

\subsection{Management of Earth Resources}

The main concerns associated with earth resources, therefore, are generally the costs and environmental impacts of extracting, transporting, and refining them. Scientists who study energy and material resources seek to understand what types of resources are available and where they can be found, and to develop new technologies for locating, extracting and exploiting them. Discovering new supplies and using more energy and materials is one way to derive more benefits. But these resources can be used more efficiently to obtain a rising amount of service from a constant level of inputs [13] [14]. Over the longer term, scientific and technological advances may enable societies to substitute new energy source and material stocks for old ones.

This typically happens when new resources perform as well as or better than current options and produce fewer negative impacts, such as pollution or health and safety risks. Energy resources and other mineral resources is the centre of development in developed countries. In situation of high cost and scarce supply of resources every part of the economy will be affected. In such situation, political leaders and major consumers want know which way forward.

However, alternating from resources to another involves more than exploration and exploitation of these resources. It also means altering the systems that produce process and distribute these resources. For example, major commercial energy fuels like coal, natural gas, and uranium are mined, cleaned, processed, refined and delivered through complex, multi-stage systems that represent billions of dollars in infrastructure investments and complicated logistical interconnections.

Facilities built for energy resources averagely operate between 30 to 50 years, hence cannot change to different resource or technology mixes over a short period of time. Retiring them prematurely to replace them with something better, is very costly even if the new plants are not more expensive than the old one [15]. Thus, as there is increase in population in developing countries and their citizens demand better service, global energy use will also continue to rise, with developing nations accounting for a growing share of total world demand.

\section{Geological and Engineering Aspects of Earth Resources Exploitation}

\subsection{Geological Aspects: Formation and Occurrence of Earth Resources}

This is concerned with the origin/formation and occurrence of non-renewable resources such as crude oil, coal, minerals, rock resources, and processing and utilization. 


\subsubsection{Oil and Natural Gas}

Petroleum is not a single chemical compound. Liquid petroleum or oil comprises a variety of liquid hydrocarbon compounds (carbon and hydrogen). There are also gaseous hydrocarbons (natural gas), of which the compound Methane $\left(\mathrm{CH}_{4}\right)$ is the most common.

The production of a large deposit of any fossil fuel requires a large initial accumulation of organic matter, which is rich in carbon and hydrocarbon. Another requirement is that the organic debris be buried quickly to protect it from the air so that decay by biological means or reaction with oxygen will not destroy it. Microscopic life is abundant over much of the oceans. When these organisms die, their remains can settle to the sea floor. There are also underwater areas near shore, such as on many continental shelves, where sediments derived from continental erosion accumulated rapidly. In such a setting, the starting requirements for the formation of oil are satisfied. There is an abundance of organic matter rapidly buried by sediments. Oil and much natural gas are believed to form from such accumulated marine microorganisms. Continental oil fields often reflect the presence of marine sedimentary rocks below the surface. Additional natural gas deposits not associated with oil may form from deposits of plant material in sediment on land.

As burial continues, the organic matter begins to change. Pressures increase with weight of the overlying sediment or rock; temperatures increase with depth in the earth; and slowly, over a long period of time, chemical reactions take place. These reactions break down the large, complex organic molecules into simpler, smaller hydrocarbon molecules. The nature of the hydrocarbons changes with time and continued heat and pressure [16].

The early stages of petroleum formation in a marine deposit, the deposit may consists mainly of larger hydrocarbon molecules (heavy hydrocarbon), which have the thick, nearly solid consistency of asphalt. As the petroleum matures, and as the breakdown of large molecules continues, successively "lighter" hydrocarbons are produced. Thick liquids give way to thinner ones, from which are derived lubricating oils, heating oil, and gasoline. In the final stages, most or all of the petroleum is further broken down into very simple, light, gaseous molecules; natural gas. Most of the maturation process occurs in the temperature range of $50^{\circ} \mathrm{C}$ to $100^{\circ} \mathrm{C}$.

The hydrocarbons can migrate out of the rocks in which they formed. Such migration is important if the oil or gas is to occur in an economically valuable and practically usable deposit. The majority of petroleum source rocks are fine grained clastic sedimentary rocks of low permeability, from which it would be difficult to extract large quantities of oil or gas quickly. Despite the low permeabilities, oil and gas are able to migrate out of their source rocks and through more permeable rocks over the long spans of geologic time [1] [16]. The pores, holes, and cracks in rocks in which fluids can be trapped are commonly full of water. Mostly oils and all natural gases are less dense than water, so they tend to rise as well as to migrate laterally through the water filled pores of permeable rocks.

The most economical deposits are those in which large quantity of petroleum has been concentrated and trapped by an impermeable rock in geologic structures.

\subsubsection{Coal}

This is formed not from marine organisms, but from the remains of land plants. A swampy setting, in which plant growth is lush and where there is water to cover fallen trees, dead leaves, and other debris, is especially favourable to the initial stage of coal formation. The process requires anaerobic conditions, in which oxygen is absent or nearly so, since reaction with oxygen destroys the organic matter.

The first combustible product formed under suitable condition is peat. Peat can form at the earth surface, and there are places on earth where peat can be seen forming today. Further burial, with more heat, pressure, and time , gradually dehydrates the organic matter and transforms the spongy peat into soft brown coal (lignite) and then to the harder coals (Bituminous and Anthracite) [16].

As the coals become harder, their carbon content increases, and so does the amount of heat released by burning a given weight of coal.

\subsubsection{Solid Minerals}

Basically, by cooling down of magma, atoms are linked into crystalline patterns and subsequently different minerals are formed. When the formation takes place in the depths of the earth's crust (approx. $33 \mathrm{~km}$ deep) quite large rocks may be formed (for instance granite).

Igneous rocks are formed and created by magmatic processes in the earth. To form very large crystals of rare 
minerals, exceptional conditions are needed. For instance, a rock called pegmatite is formed by the crystallization of magma enriched with water in the veins of other rocks, and may contain berly, tourmaline and topaz [17].

\subsection{Engineering Aspects of Earth Resources Exploitation}

This is concerned with the exploitation methods of non-renewable resources and renewable resources.

\subsubsection{Drilling of Oil and Gas Wells}

Once the site has been selected, scientists survey the area to determine its boundaries, and conduct environmental impact studies if necessary. The oil company may need lease agreements, titles and right of way accesses before drilling the land. For off-shore sites, legal jurisdiction must be determined.

After the legal issues are settled, the crew goes about preparing the land: 1) The land must be cleared and leveled and access roads may be built. 2) Because water is used in drilling, there must be a source of water nearby. If there is no natural source, the crew drills water well. 3) The crew digs a reserve pit, which is used to dispose of rock cuttings and drilling mud during drilling process, and lines it with plastic to protect the environment. If the site is an ecologically sensitive area, such as a marsh or wilderness, then the cuttings and mud must be disposed of offsite-trucked away instead of placed in a pit.

Once the land has been prepared, the crew digs several holes to make way for the rig and the main hole. A rectangular pit called a cellar is dug around the location of the actual drilling hole. The cellar provides a work space around the hole for the workers and drilling accessories. The crew then begins drilling the main hole, often with a small drill truck rather than the main rig, see Figure $\mathbf{1}$ below. The first part of the hole is larger and shallower than the main portion, and is lined with a large-diameter conductor pipe. The crew digs additional holes off to the side to temporarily store equipment. When these holes are finished, the rig equipment can be brought in and set up.

Depending upon the remoteness of the drill site and its access, it may be necessary to bring in equipment by truck, helicopter or barge. Some rigs are built on ships or barges for work on inland water where there is no foundation to support a rig [18].

\subsubsection{Surface and Underground Mining Methods}

Coal mining is the extraction of deposits from the surface of the earth and from the underground, see Figure 2. Coal mining is the most abundant fossil fuel on earth. Its predominant use has always been for producing heat energy. It was the basic energy source that fueled the industrial revolution of the $18^{\text {th }}$ and $19^{\text {th }}$ centuries, and the industrial growth of that era in turn supported the large-scale exploitation of coal deposits [19].

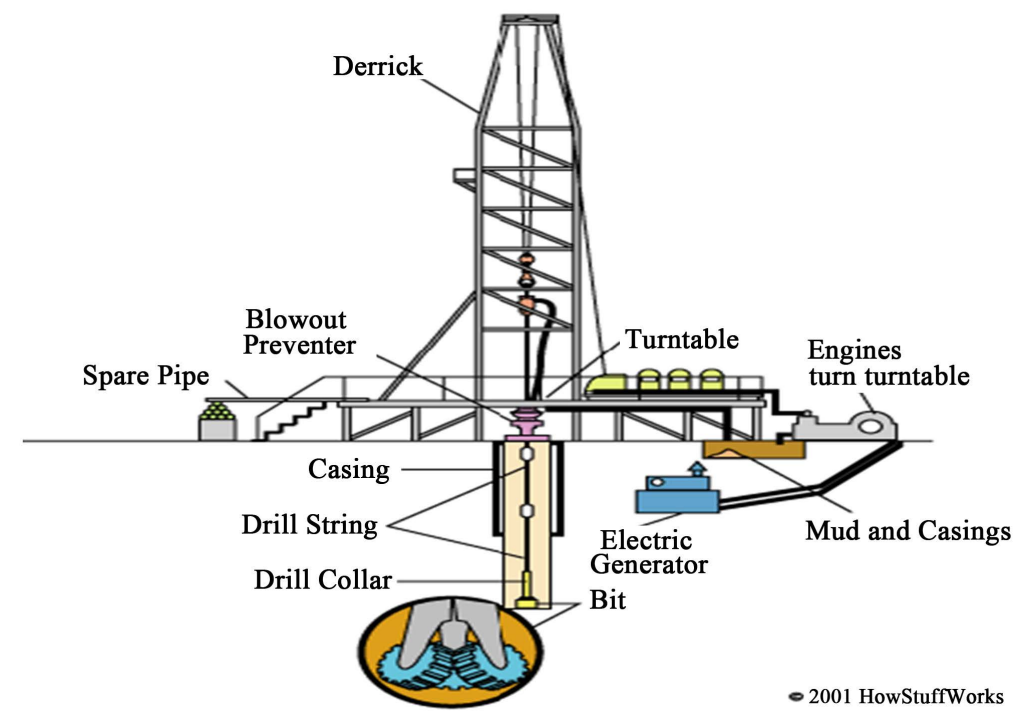

Figure 1. Rotary drilling rig (modified from Craig and Jonathan, 2001). 


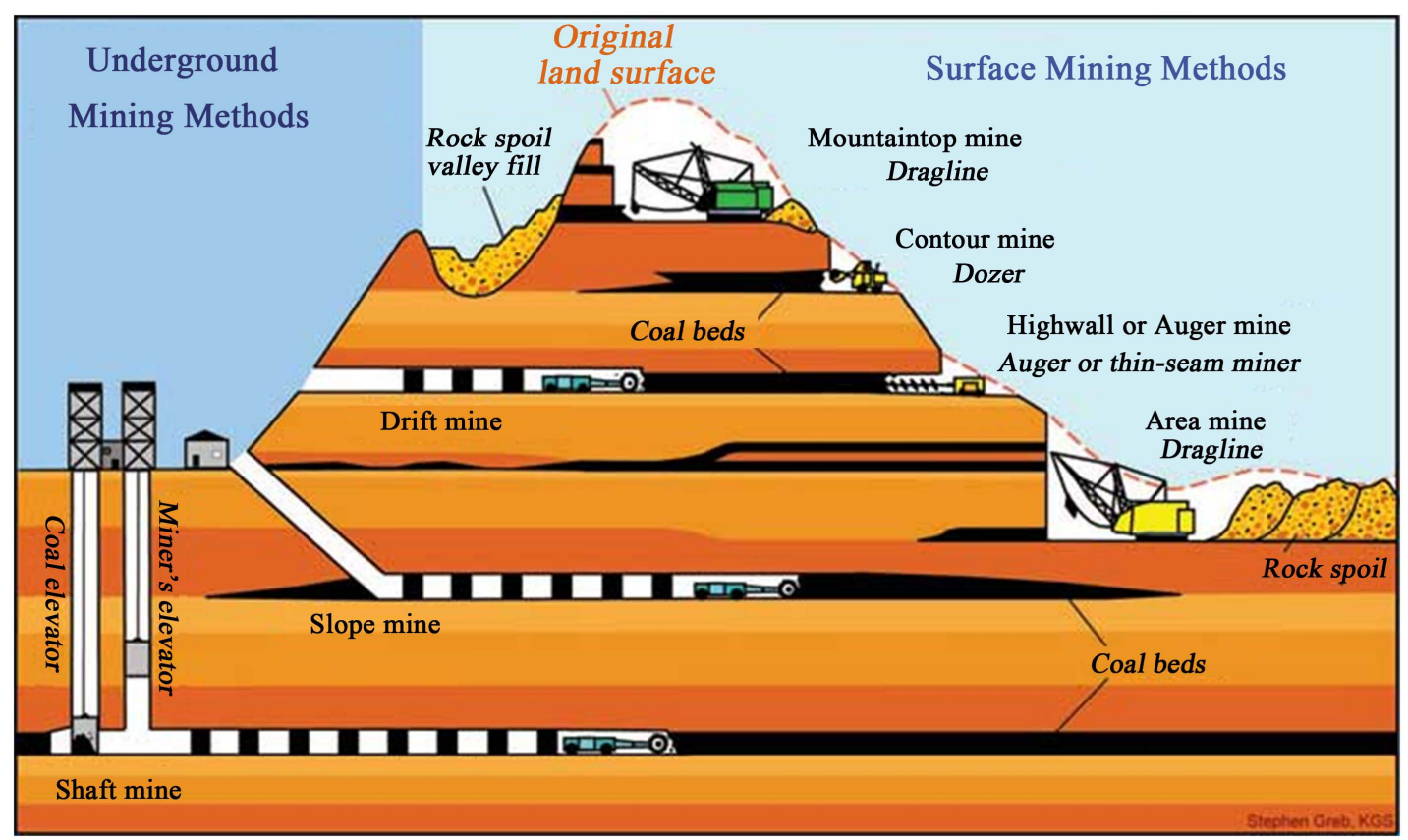

Figure 2. Different coal mining methods. Source: www.worldcoal.org/coal/coal-mining/.

The mining of coal from surface and underground deposits today is a highly productive and mechanized operation.

1) Surface Mining

Surface coal mining generally involves the following sequence of unit operations:

a) Clearing the land of trees and Vegetation.

b) Removing and storing the top layers of the unconsolidated soil.

c) Drilling the hard strata over the coal seam.

d) Fragmenting or blasting the hard strata with explosives.

e) Removing the blasted material, exposing the coal seam, and cleaning the top of the coal seam.

f) Fragmenting the coal seam, as required by drilling and blasting.

g) Loading the loose coal onto haulage conveyances.

h) Transporting the coal from the mine to the plant, and

i) Reclaiming lands affected by the mining activity.

Surface techniques can be broadly classified into:

a) Contour Strip Mining: Is commonly practiced where a coal seam outcrops in rolling or hilly terrain.

b) Area Strip Mining: Is applied where the terrain is flat, commences with a trench or box cut made through the overburden to expose a portion of the coal seam.

c) Open Pit Mining: is generally practiced where thick coal seam s overlain by thick or thin overburden. It is also used for mining steeply pitching coal seams.

d) Auger Mining: with this method, the coal is removed by drilling auger holes from the last contour cut and extracting it in the same manner that shavings are produced by a carpenter's bit.

2) Underground Mining

Here, the working environment is completely enclosed by the geologic medium which consists of the coal seam and the overlying and underlying strata. Modern underground coal mining methods can be classified into four distinct categories: (a) Room and Pillar (b) Longwall (c) Short-wall (d) Thick-seam.

Room and Pillar: Here, coal deposits are mined by cutting a network of "rooms" into the coal seam and leaving behind "pillars" of coal to support the roof of the mine.

Longwall Mining: This involves the full extraction of coal from a section of the seam or face using mechanical shearers. A long-wall face requires careful planning to ensure favourable geology exists throughout the section before development work begins. 
Shortwall: method of mining coal is best described as a method similar to longwall mining with two exceptions. The blocks of panels are smaller, usually ranging from 100 to 150 feet wide and 300 feet long and the coal is cut with a continuous miner and is loaded into shuttle cars.

\subsubsection{Processing and Utilization of Earth Resources}

Here, the occurrences and principal applications of mineral and rock resources are discussed.

1) Metals

The term mineral resource usually brings metals to mind first. The most heavily used metal is iron. And it is also one of the most common metals. Iron ore is mined from ancient sedimentary deposits, laterites and from concentrations of magnetite in some igneous bodies [20].

Aluminum is the second most widely used. Its light weight, couple with its strength, make it particularly useful in the transportation and construction industries; it is also widely used in packaging especially for beverage cans. It is the third most common element in the earth's crust, but there, it is most often found in silicates, from which it is extremely difficult to extract. Bauxite is an aluminum-rich laterite in which the aluminum is found as a hydroxide and is commercially mined for the production of aluminum [21].

Other important metals include copper, zinc, Lead, Nickel, Cobalt etc are found in sulfide ore deposits. Sulfides occur frequently in hydrothermal deposits and may also be concentrated in igneous rocks. Copper, Lead, and Zinc may also be found in sedimentary ores; some laterites are moderately rich in Nickel Cobalt [20].

Metal refining consists of purifying an impure material. It is to be distinguished from other processes such as smelting and calcining in that those two involve a chemical change to the raw material, whereas in refining, the final material is usually identical chemically to the original ore, only it is purer. The processes used are of many types including pyrometallurgical and hydrometallurgical techniques [17] [21].

2) Nonmetallic minerals

Another by-product of mining sulfides is the nonmetal sulfur. Sulfur may also be recovered from petroleum during refining, from volcanic deposits (sulfur is sometimes precipitated as pure native sulfur from fumes escaping from volcanic vents).

Several important minerals are recovered from evaporate deposits. The most abundant is halite, or rock salt, used principally as a source of the sodium and chlorine of which it is composed, and secondarily for road salt, either directly or through the production of other salts from it. Gypsum, essential to the manufacture of plaster, Portland cement, and wallboard for construction, is another evaporate mineral. Others include phosphate rock and potassium-rich potash, key ingredients of the synthetic fertilizers.

However, clay is not a single mineral, but a group of layered hydrous silicates that are formed at low temperature, commonly by weathering, and they are abundant in sedimentary deposits.

Rocks such as granite, granodiorite, diorite and other basement complex rocks are usually exploited by excavation and quarried into aggregates for engineering purposes like construction of roads, buildings, dams, and many other important structures, see Figure 3. Aggregates are used in construction to provide drainage, fill voids, protect pipes, and to provide hard surfaces. They are also used in water filtration and sewage treatment processes. Water will percolate through a trench filled with aggregate more quickly than it will through the surrounding soil, thus enabling an area to be drained of surface water. This is frequently used alongside roads in order to disperse water collected from the asphalt surfacing. The three main types of rock used to produce crushed rock aggregates are igneous, sedimentary and metamorphic [17].

\subsection{Renewable Resources Exploitation}

\subsubsection{Hydropower}

Hydropower makes use of the kinetic energy water gains when it drops in elevation; is a renewable energy source. Typically, water dammed in a lake or reservoir is released through turbines and generators to produce electricity, as shown in Figure 4. Hydropower has been a staple of electricity since the beginnings of the electric age. However, very little of this potential is currently slated for development. Significant legal and regulatory impediments, such as land acquisition and environmental protection, will be a part of any major hydro project. Additionally, reservoirs are typically built and managed as municipal water supply and flood control systems and secondarily for power production [22] [23]. 


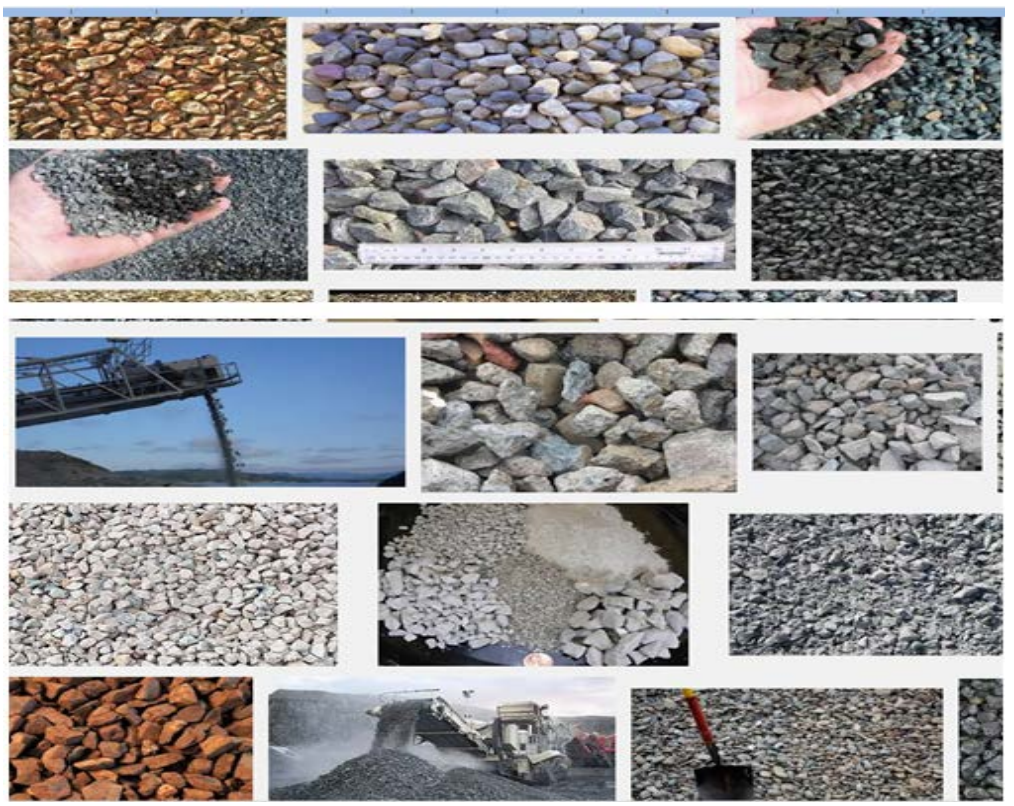

Figure 3. Rock aggregates and quarrying (modified from Adekoya, 2003).

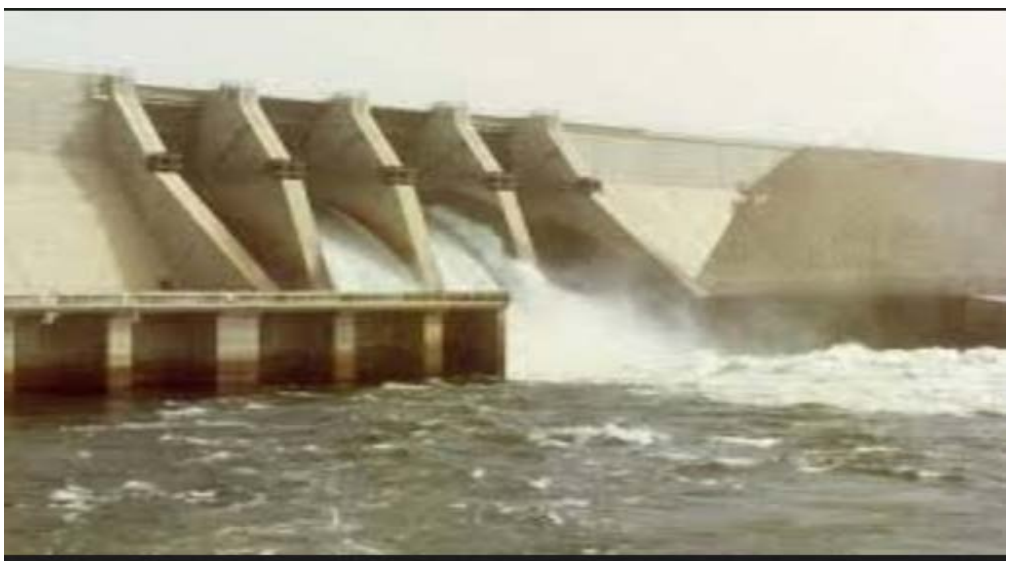

Figure 4. Kainji-dam. Sources: www.nigeriaalternativeenergy.org.

\subsubsection{Solar Energy}

Solar energy is energy in the form of electromagnetic radiation emitted from the sun and harnessed using sophisticated technologies such as solar heating, solar photo-voltaics, solar thermal energy, solar architecture and artificial photosynthesis. It is one of the most important sources of renewable energy and its technologies are categorized as either passive solar or active solar depending on the way they capture and distribute solar energy or convert it into solar electricity (power). Active solar methods include the use of photovoltaic systems, concentrated solar power and solar water heating to tap the energy. Passive solar methods include orienting a building to the Sun, selecting materials with advantageous thermal mass or light dispersing properties, and designing spaces that naturally circulate air. Businesses and industry also use these methods to diversify their energy sources, improve efficiency, and save cost. Solar photovoltaic and concentrating solar power methods are also being used by developers and utilities to produce electricity to power houses both residential and commercial [23] [24].

\subsubsection{Geothermal Energy}

Geothermal energy is the heat from the Earth. It is clean and sustainable. Resources of geothermal energy range from the shallow ground to hot water and hot rock found a few miles beneath the Earth's surface, and down even 
deeper to the extremely high temperatures of molten rock called magma. Of all the elements of a geothermal system, the heat source is the only one that need be natural. Providing conditions are favourable, the other two elements could be "artificial". For example, the geothermal fluids extracted from the reservoir to drive the turbine in a geothermal power-plant could, after their utilization, be injected back into the reservoir through specific injection wells [22]. In this way the natural recharge of the reservoir is integrated by an artificial recharge. For many years now re-injection has also been adopted in various parts of the world as a means of drastically reducing the impact on the environment of geothermal plant operations [24].

\subsubsection{Ocean Energy (Waves and Tides)}

Three distinct types of ocean resource are commonly mentioned as possible energy sources: tides, waves, and ocean temperature differentials (ocean thermal energy conversion, or OTEC). For example, tidal energy schemes capture water at high tide and release it at low tide. Wave energy generation devices fall into two general classifications, fixed and floating. In both cases, the oscillating motion of an incoming and outgoing wave is used to drive turbines that generate electricity. Tide energy systems traps high tides in a reservoir. When the tide drops, the water behind the reservoir flows through a power turbine, generating electricity. Ocean thermal energy conversion uses the difference in temperature between warm surface water and cold deep ocean water to make electricity [21] [24].

\subsubsection{Surface and Groundwater}

Water is usually contained naturally in aquifers or as surface water both of which are deposited by geological process known as water cycle. Exploitation is usually by drilling boreholes or wells to access their aquifers or direct access to surface sources such as rivers, lakes and so on. Water wells are excavations or structures created in the ground by digging, driving, boring, or drilling to access groundwater in underground aquifers. They are drawn by pumps, or by using containers, such as buckets, that are raised mechanically or by hand. Water may flow to the surface naturally after excavation of the hole or shaft. Such a well is known as a flowing artesian well. In numerous recently published state-of-the-environment reports, water turns out to be the factor most limiting sustainable development. In the next decade the availability of fresh water will dictate all agendas of development, not only in developing countries, and might cause political instability in larger dry regions on Earth. .The availability of fresh potable water is seriously restricted by:

1) Depletion of aquifers; and

2) Pollution of both surface and groundwater resources. The problem of aquifer depletion is partly caused by inadequate aquifer management (over-exploitation, poor recharge, etc.) but mainly by the fact that ever-smaller quantities of fresh groundwater will have to supply more and more people on earth [21] [25].

\subsection{Environmental Problems of Earth Resources Exploitation and Their Mitigation}

The most obvious and severe disruptions of the natural environment have come from the exploitation of resources. Mining, quarrying, dredging, and the drilling and extraction of oil and gas from wells are all activities that have made irreversible impacts on the landscape and therefore on the environment. Directly linked to the extraction activities are issues concerned with the disposal of the waste product that accompany extraction [1].

Further environmental problems may be caused at the site of exploitation when various extraction or concentration processes are employed. For example, most metal mines remove an ore that contains only a very small proportion of the metal being extracted. Various physical and chemical processes, often culminating in smelting, are then needed to extract the metal from the mined ore. For metal extraction, at least three aspects of the process create potential environmental problems: the mining operation, the disposal of very large quantities of waste rock, and the processing, smelting, and refining of the ore [26] [27].

\subsubsection{Environmental Impact of Oil and Gas Exploitation}

The exploitation of Oil and gas drilling can pose adverse health and environmental impacts, from contamination of surface and underground water system with drilling mud and fluids. Offshore and onshore drilling can cause blowout and put the life of oil workers at risk. Spills and leakages may occur and pollute ocean waters or close land areas, either as a result of industrial accidents or through storm damage to drilling rigs or Formation pressure upsurge. Oil spills from wells are not uncommon and can pollute vast areas both offshore and onshore, generating clear and measurable environmental impacts. In Nigeria, an estimated 260,000 barrels of oil $\left(41,000 \mathrm{~m}^{3}\right)$ 
spill each year into the Niger Delta and surrounding areas, with devastating impacts on people, plants, and wildlife. Marine spills such as these can lead to freshwater system contamination when the oil hits the shoreline and drifts up through estuaries into streams. From extraction to end use, petroleum products affect surface water and groundwater, impairing water quality with hydrocarbons, salts, nutrients, a host of organic compounds, and various heavy metals. Movement of oil and gas from wells to processors needs enormous facilities and such creates environmental risks. Pipelines and tankers are used in the world today to convey oil and gas, both of which are prone to spills. Producers convey crude oil from the well via pipelines or ships to refineries, where crude oil is distilled into a variety of petroleum products, including gasoline, kerosene, fuel oils, liquefied petroleum gas, various lubricants, asphalt, and precursors to plastic and pharmaceutical products, among others. These petroleum products are then distributed via various modes to other manufacturers and to end users. Each of these steps can affect surface water sources negatively. After production, crude oil is refined through a series of water-intensive processes: water is used for steam, as part of the refining process, as wash water, and for cooling. Process water typically becomes contaminated with sulphur and ammonia, requiring treatment [13] [28].

\subsubsection{Impacts of Mining and Quarrying}

Most of the impacts arising from mining and quarrying are obvious. They include the disruption of land otherwise suitable for agricultural, urban, or recreational use; the deterioration of the immediate environment through noise and airborne dust; and the most dangerous for its workers and is potentially also hazardous for the public.

The generation of sulfuric acid can occur when hazardous minerals are exposed to air in underground mines or in open pits, or in the dumps of waste materials left by mining operations. Water passing through the mines or dumps becomes acidified and then can find its way into rivers and streams or into the groundwater system [16].

\subsubsection{Acid Rain}

Rainfall is generally thought of as beneficial, washing and watering Earth's surface. While this is still true in many places, the image of rainfall has become tarnished because we now know that rainfall is not always pure water and its effects are not always beneficial. As early as 1872, the British chemist Robert Smith coined the term "acid rain" to describe precipitation containing significant amounts of sulfuric acid. He attributed the acid to the burning of the coal that fueled the furnaces of the Industrial Revolution.

Rainwater naturally contains dissolved carbon dioxide from the atmosphere that forms weak carbonic acid, $\mathrm{H}_{2} \mathrm{CO}_{3}$. This acid ionizes, forming $\mathrm{H}^{+}$and $\mathrm{HCO}_{3}^{-}$ions, resulting in rainfall that is normally slightly acid with a $\mathrm{PH}$ of about 5.6. The increase of carbon dioxide due to the burning of fossil fuels has some significant effects on atmospheric warning, but lowers $\mathrm{pH}$ only slightly [29] [30].

However, the introduction of large amounts of sulfur oxides and nitrogen oxides into the atmosphere by the combustion of fossil fuels has a significant impact on the acidity of rainwater. Sulfur oxides, which react with water vapor to form sulfuric acid $\left(\mathrm{H}_{2} \mathrm{SO}_{4}\right)$, are created when sulfur bearing-minerals in coal are burned. Nitrogen oxides, which react with water vapor to form nitric acid $\left(\mathrm{HNO}_{3}\right)$, are created as an unintentional by-product of high temperature combustion in an atmosphere containing 78 percent nitrogen. Small amounts of these two strong acids in rainfall can sharply lower the $\mathrm{pH}$ of rainwater [28].

\subsubsection{Acid Mine Drainage}

This is refers to the outflow of acidic water from abandoned metal mine or coal mine.

Acid mine drainage is also the formation and movement of highly acidic water rich in heavy metals, see Figure 5. This acidic water forms through the chemical reaction of surface water and shallow subsurface water with rocks that contain sulfur-bearing minerals, resulting in sulfuric acid. Heavy metals can be leached from rocks that come in contact with the acid, a process that may be substantially enhanced by bacterial action. The resulting fluids may be highly toxic and, when mixed with groundwater, surface water and soil, may have harmful effects on humans, animals and plants [19].

\subsubsection{Impacts Mitigation}

Mining is a relatively short-term activity, and much can be done to both limit environmental damage during mining and to restore the land when mining operations are complete:

All mining operations generate waste rock, often in very large amounts; the waste can be used in reclamation and backfilling when treated [1]. 


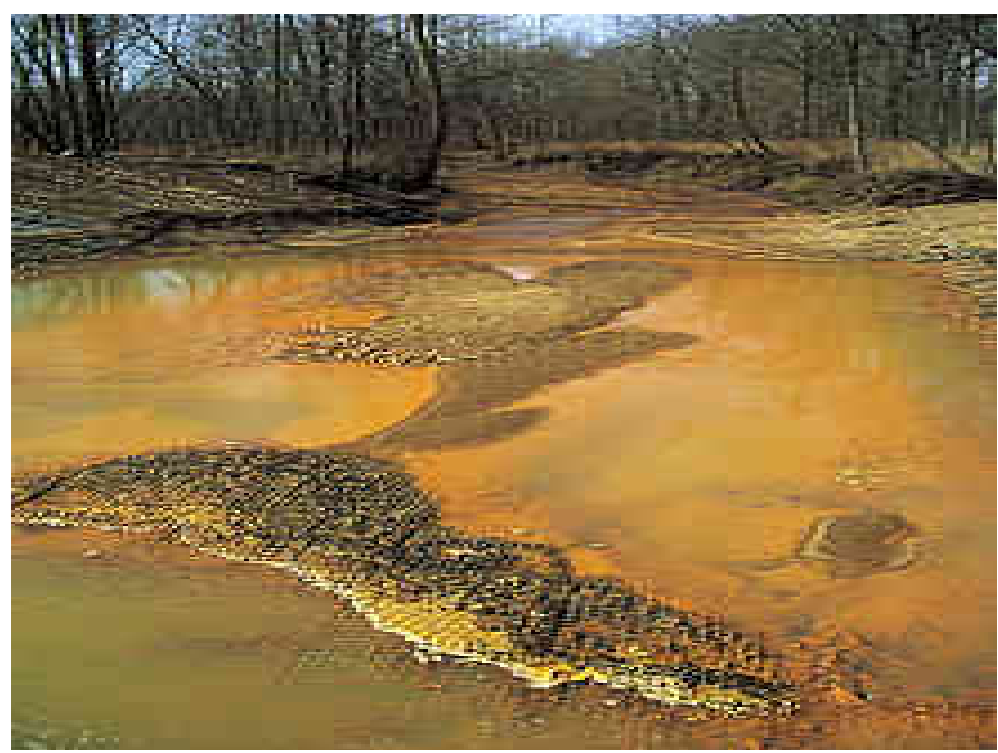

Figure 5. Acid mine drainage. Source: www.worldcoal.org/coal/coal-mining/.

Meanwhile, planning the mining layout so as to have the least requirement of the forest land and take necessary steps for reclamation of the mined out land so that the forest land taken for mining purposes can be brought back to forest.

The noise and vibration producing activities in the mines and associated activities be planned to have the minimum possible intensity and impact on the living organisms in the surrounding area.

Use of dust extractors with the drill machines can be expected to minimize air pollution due to drilling. However, optimizing the blast design and proper maintenance of the haul roads can minimize the generation of air borne dust [16].

Countries, both developing and developed, should aim at using cleaner, less polluting technologies in earth resources exploitation. Use of these technologies aids mitigation and could result in substantial reductions in $\mathrm{CO}_{2}$ emissions. Also, use of scrubbers to reduce the escape of obnoxious gases into the atmosphere during burning of fossil fuels [30].

\section{Case History of Environmental Aspects of Aggregate Exploitation in Imo State, Nigeria}

Several organization and individuals are involved in aggregate production in Imo State. Most of the organizations obtain quarry leases from Imo State Government to operate quarries where construction materials are mined and processed [31] [32]. Some of the organizations involved in aggregate production in Imo State are shown as Table 1.

According to Okeke, the locations of the quarries are related to the geology of the area [31]. Two types of natural aggregates are produced in Imo State, and they include: sand/gravel aggregate from Benin Formation in relatively flat low-lying southern part of the state (Owerri, Isu and Oru L.G.As) and crushed sandstone in the undulating northern part of the state (Okigwe and Ihite Uboma L.G.As). Sands and gravels are excavated by hand tools of shovels and diggers on land and by panning and dredging from rivers (particularly rivers Otamiri and Njaba). Sand and gravels are usually produced together but later screened to separate them into different fractions. The quarrying of sandstone in Okigwe and Ihite Uboma areas involve three processes of removal of top soil, excavation of sandstone boulders, and crushing to suitable commercial sizes of usually $25 \mathrm{~mm}$ and 50 $\mathrm{mm}$.

\section{Coal Mining in Enugu Nigeria}

In the Enugu coal mines, both the Onyeama mine and Okpara mine were flooded after the Nigerian crises (of 1967-1970). Coal was first discovered in Enugu in 1907. The Enugu coal is associated with the highly fractured 
Table 1. Organizations involved in aggregate production in Imo state.

\begin{tabular}{ccc}
\hline Organization & Type of aggregate & Quarry location \\
\hline Owerri Sand/Gravel Association & River sand/gravel & Nekede and Ihiagwa (Owerri West LGA) \\
Bathoway Dredging & River sand & Nekede \\
S. O Amadi and Co & Sand/gravel & Nekede \\
Electroshed Dredging & Sand/gravel & Nekede \\
Awomamma Sand/Gravel association & Sand/gravel & Awomamma (Oru East LGA) \\
Okwudor Sand/Gravel Association & Sand/gravel & Okwudor (Njaba LGA) \\
Ikperejere Crushed Rock Association & Sandstone & Ikperejere (Ihite Uboma LGA)
\end{tabular}

(Modified from Okeke, 2001).

Mamu Formation (Lower coal measures) with intercalations of shale and sandstone [33]. The Mamu Formation itself was underlain by Enugu Shale and overlain by frible Ajali Formation [34]. The Onyeama mine was opened in 1958 and mechanized in 1977. Unfortunately the longwall mining method at Onyeama mine intercepted the major fault systems that contributed to the flooding of the mines. The Okpara mine was also flooded by surface drainage through the permeable Ajali Formation. Only Okpara mine is in operation at the moment at Enugu. This is because its flooding was not as bad as that of Onyeama mine and its always controlled [35] [36].

\section{Summary and Conclusion}

Earth resources are materials provided by the Earth and useable to humans to make more complex (humanmade) products. In a more simplified explanation, earth resources also referred to as natural resources which are useful raw materials gotten from the Earth. Earth resources are basically divided into renewable, flow and nonrenewable resources. Sustainable development has to do with meeting the basic needs of people today without ruining the chances of future generations to do the same. Exploitation of earth resources produces so many benefits to mankind as well as associated problems ranging from environmental impacts to their depletion. The issue of depletion plays an important role in the use of non renewable and renewable earth resources. For renewable resources, depletion occurs when extraction exceeds renewal rate. Flow and environmental resources are not depleted and always exist. Major consequence of our exploiting earth resources is that we are interfering with the balance of some natural geochemical cycles (for example, carbon/sulphur cycles). Geological, engineering, environmental and economic factors control mineral availability. The adequacy of world mineral reserves and resources is strongly affected by consumption, stockpiles and recycling. However, mineral recycling and substitution alongside transfer of technology from industrially developed to developing nations will contribute significantly to sustainable development of these resources [37]. Geoscientists can and must contribute to solving the basic problems of mankind in the next decade, even more than today.

\section{Acknowledgements}

We happily acknowledge the effort of Engr. Dr. O. C. Okeke whose guidance made this work a huge success.

\section{References}

[1] Craig, J.R., Vanghorn, D.J. and Skeinner, B.J. (2011) Earth Resources and the Environment. 72-88.

[2] WCED (1987) Our Common Future. World Commission on Environment and Development United Nations.

[3] Robinson, J.G., Francis, G., Legge, R. and Lemer, S. (1990) Defining a Sustainable Society. Alternatives, 2, 36-46.

[4] Marconick, R. (1990) Environment and Concept of Sustainable Development. Proceedings, Workshop on the Environment and Sustainable Development in Nigeria, 25-26 April 1989, Abuja, 44-52.

[5] Lawrence, D.P. (1997) Integrating Sustainability and Environmental Impact Assessment. Environment Management, 21, 23-42. http://dx.doi.org/10.1007/s002679900003

[6] McNicoll, G. (2007) Population and Sustainability. Handbook of Sustainable Development. Edward Elgar Publishing, 125-139. http://dx.doi.org/10.4337/9781847205223.00016

[7] Milbraith, L.W. (1989) Envisioning a Sustainable Society. State University of New York Press, Albany, 400 p. 
[8] Nju, W.Y., Lu, J.J. and Khan, A.A. (1993) Spatial Systems Approach to Sustainable Development: A Conceptual Frame Work. Environmental Management, 17, 179-186.

[9] Pedro, A.M.A. (2004) Mainstreaming Mineral Wealth in Growth and Poverty Reduction Strategies. Economic Commission for Africa, Addis Ababa, 5-6.

[10] Pegg, S. (2006) Mining and Poverty Reduction: Transforming Rhetoric into Reality. Journal of Cleaner Production, 14, 376-387.

[11] Planas, F. (2012) The Exploitation of Environmental Resources. Un An Pour La Planete.

[12] WCED (1992) Our Common Future. World Commission on Environment and Development United Nations.

[13] Environmental Protection Agency (2010) Assessing the Multiple States, Chapter 5.

[14] Weber-Fahr, M., Strongman, J., Kunanayagam, R., McMahon, G. and Sheldon, C. (2001) Mining and Poverty Reduction. Noor Internationaal WB PRSP Sourcebook, 4-6.

[15] Bray, J. (2003) Attracting Reputable Companies to Risky Environments: Petroleum and Mining Companies. Environmental Resources and Conflict: Options and Actions. World Bank Publications, 287-347.

[16] Carla, W.M. (2011) Environmental Geology. McGraw-Hill Publishing, 511 p.

[17] Adekoya, J.A. (2003) Environmental Effect of Solid Minerals Mining. J. Phys. Sci. Kenya, 625-640.

[18] Craig, F. and Jonathan, S. (2001) How Oil Drilling Works. Newsletter of Science and Environmental Science.

[19] www.worldcoal.org/coal/coal-mining/

[20] Day, J. and Tylecote, R.F. (1991) The Industrial Revolution in Metals. Institute of Metals, London.

[21] John, P.H., Barry, J.H., John, F.P., William, P.I. and Ramachandran, V. (1994) Extraction and Processing for the Treatment and Minimization of Wastes. The Mineral, Metals and Materials Society, Pennsylvania.

[22] www.nigeriaalternativeenergy.org

[23] Ibidapo-Obe, O. and Ajibola, O.E. (2011) Towards a Renewable Energy Development for Rural Power Sufficiency.

[24] Temilade, S. (2008) Status of Renewable Policy and Implementation Nigeria. Institute for Science and Society, University of Nottingham, Nottingham.

[25] Gleick, P.H. (1993) Water in Crisis. In: Gleick, P.H., Ed., A Guide to the Worlds Freshwater Resources. Pacific Institute for Studies in Development, Environment and Stockholm Environmental Institute, Oxford University Press, London.

[26] Balkau, F. (2000) Cyanide Management in Gold Mining: An International Code. International Council on Metals and the Environment Newsletter, 8, 4.

[27] Brereton, D. and Forbes, P. (2004) Monitoring the Impact of Mining on Local Communities: A Hunter Valley Case Study. CSRM, 12-13.

[28] Aigbedion, I.N. (2005) Environmental Pollution in the Niger-Delta, Nigeria. Inter-Discplinary Journal of EnuguNigeria, 3, 205-210.

[29] Federal Environment Protection Agency (FEPA) (1989) National Policy on the Environment. Federal Environment Protection Agency Abuja, Nigeria.

[30] Federal Environment Protection Agency (FEPA) (1991) National Interior Guidelines and Standards for Industrial Effluents, Gaseous Emission and Hazardous Waste Management in Nigeria. Federal Environment Protection Agency, Abuja.

[31] Okeke, O.C. (2001) Assessing the Sustainability of Aggregate Production in Imo State, Nigeria. Journal of Management Technology, 3, 183-189.

[32] Okeke, O.C. and Uzoh, O.F. (2009) Towards Achieving Sustainable Water Resources Management in Nigeria. Global Journal of Geological Sciences, 7, 85-92. http://dx.doi.org/10.4314/gjgs.v7i1.45162

[33] Simposn, A. (1954) The Nigerian Coalfield. Geological Survey of Nigeria Bulletin, Abuja.

[34] Reyment, R.A. (1965) Aspects of Geology of Nigeria. Ibadan University Press, Ibadan.

[35] Okeke, O.C. (2005) Grouting and Dewatering in Engineering Practice. ADSON Educational Publishers, Onitsha.

[36] Okeke, O.C. (1991) Role of Mineral Raw Materials in the Development of Indigenous Building Materials Industry in Nigeria. Journal of Mining Geology, 27.

[37] (2011) International Conference on Innovations in Engineering and Technology (IET), 8-10 August 2011. 